\title{
Hubungan somatotype dengan kesegaran jasmani atlet sepak bola
}

\author{
Elok Dwi Anggitasari, Fillah Fithra Dieny *, Aryu Candra \\ Departemen Ilmu Gizi, Fakultas Kedokteran, Universitas Diponegoro \\ Jalan Prof. Soedarto, S.H. Tembalang, Kota Semarang, Jawa Tengah, Indonesia \\ * Corresponding Author. E-mail: fillahdieny@ gmail.com, phone +62856-4020-4747
}

Received: 13 July 2018; Revised: 20 September 2018; Accepted: 21 September 2018

\begin{abstract}
Abstrak
Penelitian ini bertujuan untuk mengetahui hubungan somatotype dengan kesegaran jasmani atlet sepak bola. Desain penelitian cross sectional dengan sampel sebanyak 42 subjek dipilih secara random sampling. Data somatotype didapatkan dari pengukuran antropometri terdiri dari berat badan, tinggi badan, trisep, suprailiaca, subscapular, calf skinfold, humerus width, fumerus width, dan flixed arm girth yang dihitung dengan metode antropometri Heath-Carter untuk menghasilkan skor somatotype yaitu endomorph, mesomorph, dan ectomorph. Data kesegaran jasmani diperoleh dengan tes ACSPFT (Asian Committee on the Standarization of Physical Fitness Test) terdiri dari tes kecepatan, daya ledak otot, ketangkasan, kelenturan, dan kekuatan. Data asupan zat gizi diperoleh dengan metode food recall 3x24 jam. Data dianalisis menggunakan uji chi-square dan kolmogorov-smirnov. Dari semua subjek diperoleh $19 \%$ memiliki tipe tubuh endomorph, 26.2\% mesomorph, dan 54.8\% ectomorph. Secara keseluruhan subjek memiliki kesegaran jasmani $73.8 \%$ baik, $21.4 \%$ sedang, dan $4.8 \%$ kurang. Ada hubungan somatotype dengan kecepatan $(p=0,034)$, daya ledak otot $(p=0.0001)$, ketangkasan $(p=0.0001)$, kelenturan $(p=0.041)$, kekuatan $(p=0.003)$ dan kesegaran jasmani $(p=0.045)$. Tipe ectomorph dan dan mesomorph memiliki komponen kesegaran jasmani lebih baik dibandingkan tipe endomorph. Asupan energi $(p=0.035)$ dan somatotype $(p=0.045)$ merupakan variabel yang paling berpengaruh terhadap kesegaran jasmani
\end{abstract}

Kata Kunci: somatotype, kesegaran jasmani, atlet, sepak bola

\section{Correlation of somatotype with physical fitness of football athletes}

\begin{abstract}
The aim of this study is to analyze the correlation of somatotype with physical fitness in football athletes. A cross sectional study with 42 subjects was selected by random sampling. Somatotype assessed with anthropometric measurements consists of weight, height, tricep, suprailiaca, subscapular, skinfold calf, humerus width, fumerus width, flixed arm girth. The somatotype components were calculating Heath-Carter anthropometric method to obtained somatotype score endomorph, mesomorph, and ectomorph. Physical fitness were obtained by the ACSPFT (Asian Committee on the Standarization of Physical Fitness Test) consists of speed, muscular explosive power, agility, flexibility, and strength. Data of nutrient intake were obtained by food recall method $3 \times 24$ hours. Data analyzed by chi-square and kolmogorov-smirnov test. Subjects were 19\% endomorph, 26.2\% mesomorph, and 54.8\% ectomorph. Overall subjects had a good physical fitness $73.8 \%, 21.4 \%$ moderate, and $4.8 \%$ less. There were various somatotype correlation with speed $(p=0.034)$, muscle explosive power $(p=0.0001)$, agility $(p=0.0001)$, flexibility $(p=0.041)$, strength $(p=0.003)$ and physical fitness $(p=0.045)$. The ectomorph and mesomorph types had better physical fitness components than the endomorph type. Energy intake $(p=0.035)$ and somatotype $(p=0.045)$ were the most influential variables on physical fitness.
\end{abstract}

Keywords: somatotype, physical fitness, athlete, football

How to Cite: Anggitasari, E., Dieny, F., \& Candra, A. (2019). Hubungan somatotype dengan kesegaran jasmani atlet sepak bola. Jurnal Keolahragaan, 7(1), 11-22. doi:https://doi.org/10.21831/jk.v7i1.21188

do https://doi.org/10.21831/jk.v7i1.21188

\section{PENDAHULUAN}

Olahraga merupakan salah satu cara untuk meningkatkan ketahanan fisik sekaligus sebagai upaya untuk memelihara kesehatan dan kebugaran, sarana pendidikan hingga pada pencapaian prestasi (Departemen Kesehatan Republik 
Jurnal Keolahragaan 7 (1), 2019 - 12

Elok Dwi Anggitasari, Fillah Fithra Dieny, Aryu Candra

Indonesia, 2005). Performa atlet merupakan salah satu penentu kemenangan pada sebuah pertandingan. Performa atlet pada sebuah pertandingan berhubungan dengan berbagai hal yaitu kemampuan yang dimiliki, psikologi atlet, kesegaran jasmani, dan latihan yang dilaksanakan sebelum pertandingan (Irianto, 2007). Teknik atau kemampuan yang dimiliki atlet dipengaruhi oleh kondisi fisik, dimana atlet dituntut mempunyai bentuk tubuh yang proporsional (Berning, 2004; Whitney \& Rolfes, 2007). Kondisi fisik merupakan faktor yang cukup penting untuk mempertahankan atau meningkatkan kesegaran jasmani atlet (Ulvie \& Setiwati, 2011).

Sepak bola merupakan olahraga beregu atau tim yang membutuhkan ketrampilan yang berhubungan dengan kesegaran jasmani yaitu kekuatan otot, kecepatan, kelenturan, ketangkasan, keseimbangan, dan koordinasi yang baik.Pemain sepak bola juga harus memperhatikan posisi pemain seperti seorang pemain gelandang (tengah) dan belakang tengah mempunyai jarak tempuh yang lebih tinggi dari pada pemain lainnya saat bertanding (Widyastuti \& Agus, 2007). Penelitian pada atlet sepak bola profesional PSIS Semarang memiliki kesegaran jasmani dengan kurang masih banyak ditemukan sebanyak 42,2\% (Fink, Burgon, \& Mikesky, 2006).

Kesegaran jasmani merupakan kemampuan untuk melakukan kegiatan atau pekerjaan sehari-hari dan adaptasi terhadap perubahan fisik tanpa menimbulkan kelelahan berlebih (Widyastuti \& Agus, 2007). Kesegaran jasmani dipengaruhi oleh dua faktor utama yaitu faktor internal dan eksternal. Faktor internal meliputi genetik, umur dan jenis kelamin sementara faktor eksternal meliputi aktivias fisik, kelelahan, lingkungan dan kebiasaan merokok serta faktor lain seperti status kesehatan, komposisi tubuh dan status gizi. Kesegaran jasmani atlet sepak bola sangat dibutuhkan karena atlet sepak bola harus bermain 2 x 45 menit (Widyastuti \& Agus, 2007).

Somatotype atau tipe tubuh adalah keadaan tubuh dari seseorang yang sangat menentukan kesesuaian dalam aktivitas fisik pada suatu cabang olahraga. Somatotype atlet pada cabang olahraga tertentu memiliki karakteristik yang berbeda dan spesifik. Somatotype atlet yang sesuai dengan cabang olahraga yang digeluti ternyata sangat mendukung performa atlet, seperti halnya atlet sepak bola mampu memberikan kontribusi terhadap terbentuknya tingkat kebugaran yang dimiliki. Tipe tubuh dapat diperoleh dari frekuensi dan intensitas dalam melakukan aktivitas fisik yang dapat meningkatkan tingkat kebugaran. Tingkat kebugaran yang baik dapat diperoleh dengan pola aktivitas fisik yang teratur dan terprogram dengan baik. Dengan adanya pola permainan dan peraturan permainan yang berbeda-beda ini tentunya akan memberikan perbedaan pada kualitas kebugaran yang dimiliki (Tóth, Michalíková, Bednarčíková, Živčák, \& Kneppo, 2014).

Atlet sepak bola memerlukan adanya kesesuaian dengan pertimbangan tipe tubuh. Selama ini program pemilihan atlet hanya ditentukan dari prestasinya semata atau kemampuan dalam bertanding, padahal untuk memperoleh prestasi yang maksimal dibutuhkan suatu kondisi pemain yang memiliki kemampuan fisik, teknik, taktik yang baik serta didukung oleh kondisi somatotype (tipe tubuh) yang baik pula (Evendi, 2015). Tipe tubuh dan kualitasnya merupakan hal yang sangat penting dalam melakukan aktivitas. Bentuk tubuh dan kualitasnya akan berpengaruh positif bila disesuaikan dengan aktivitas yang dilakukan guna mencapai hasil kerja yang maksimal (Fink et al., 2006; Tóth et al., 2014).

Penentuan tipe tubuh pada olahraga sepak bola dihitung menggunakan metode antropometri Heath-Carter meliputi pengukuran berat badan, tinggi badan, tebal lemak tubuh, lebar tulang, dan lingkar tubuh. Pengukuran tipe tubuh menggunakan antropometrikurang mendapat perlakuan secara tepat, padahal untuk mencapai puncak prestasi seorang atlet cabang olahraga sepak bola diperlukan tipe tubuh dengan karakteristik tertentu (Heath \& Carter, 2002). Secara garis besar tipe tubuh manusia terdiri atas: tipe endomorph memiliki ciri-ciri badan bulat dengan lemak banyak, kepala besar dan bulat, tulang-tulang pendek, leher pendek, konsentrasi lemak pada perut dan dada, bahu sempit, dada berlemak, tangan pendek, pantat besar, tungkai dan pinggang lebar. Tipe mesomorph memiliki ciri-ciri tubuh persegi, otot-otot kuat dan keras, tulang-tulang besar dan tertutup otot yang tebal, kaki, togok, lengan umumnya massif (pejal atau berat) dengan otot-otot kuat, togok besar dan relatif mempunyai pinggang yang langsing, bahu lebar, sedangkan tipe ectomorph pada umumnya langsing, tubuh kecil, tulang kecil dengan otot-otot yang tipis, lengan dan tungkairelatif panjang dengan togok pendek, ini tidak berarti orang tersebut selalu tinggi, perut dan tulang belakang merata, dada relatif tajam dan naik, bahu sempit, dan jalur otot tidak terlihat (Heath \& Carter, 2002). Berdasarkan uraian tersebut, tujuan penelitian ini adalah untuk menganalisis hubungan antara hubungan 
Jurnal Keolahragaan 7 (1), 2019 - 13

Elok Dwi Anggitasari, Fillah Fithra Dieny, Aryu Candra

somatotype dengan kesegaran jasmnai atlet sepak bola.

\section{METODE}

Penelitian ini termasuk dalam ruang lingkup keilmuan gizi masyarakat dengan desain penelitian cross-sectional. Subjek penelitian adalah atlet sepak bola tim Porprov Kota Semarang dan atlet sepak bola EPFC Semarang yang dipilih secara simple random sampling berdasarkan kriteria inklusi dan eksklusi. Kriteria inklusi antara lain bersedia menjadi subjek penelitian dengan mengisi informed-consent, terdaftar sebagai alet sepak bola, tidak merokok, dan tidak sedang cedera atau dalam perawatan dokter. Sedangkan kriteria eksklusi dalam penelitian ini adalah subjek tidak menjalankan semua tahap selama penelitian dilakukan dan subjek keluar dari anggota klub sepak bola. Besar sampel dihitung menggunakan rumus dan didapatkan jumlah keseluruhan sampel dalam penelitian ini adalah 42 orang. Variabel terikat pada penelitian ini adalah kesegaran jasmani dan variabel bebas adalah somatotype. Sedangkan variabel perancu dalam penelitian ini adalah asupan energi, karbohidrat, protein, dan lemak.

Somatotype sangat menentukan kesesuaian dalam aktivitas fisik pada suatu cabang olahraga. Kategori somatotype atau tipe tubuh diperoleh dengan melakukan serangkaian pengukuran antropometri meliputi berat badan, tinggi badan, pengukuran tebal lemak tubuh (trisep, suprailiaca, subcapular, dan calf), lebar tulang (humerus width dan fumerus width), lingkar tubuh (flixed arm girth, calf girth). Berat badan diukur menggunakan timbangan digital dengan ketelitian $0,1 \mathrm{~kg}$, tinggi badan diukur menggunakan microtoise dengan ketelitian $0,1 \mathrm{~cm}$, ketebalan lemak tubuh diukur menggunakan skinfold dengan ketelitian $0,1 \mathrm{~mm}$, lebar tulang diukur menggunakan sliding caliper dengan ketelitian $0,1 \mathrm{~mm}$, dan lingkar tubuh diukur menggunakan metlin dengan ketelitian $0,1 \mathrm{~cm}$. Setelah semua komponen somatotype diukur, kemudian hasil pengukuran dimasukkan kedalam rumus menurut metode antropometri Heath-Carter (dalam lampiran) untuk mendapatkan masing-masing skor endomorph, mesomorph, dan ectomorph. Dikategorikan endomorph apabila skor endomorph lebih dominan dari skor mesomorph dan ectomorph, dikategorikan mesomorph apabila skor mesomorph lebih dominan dari skor endomorph dan ectomorph, sedangkan dikategorikan ectomorph apabila skor ectomorph lebih dominan dari skor endomorph dan mesomorph (Heath \&
Carter, 2002). Tiga tipe tubuh tersebut diperinci menjadi empat kategori yaitu endomorphy ectomorph, mesomorphic ectomorph, endomorphic mesomorph, dan mesomorphic endomorph. Kategori endomorphy ectomorph adalah ectomorph lebih dominan dan endomorph lebih besar dari pada mesomorph. Kategori mesomorphic ectomorph adalah ectomorph lebih dominan dan mesomorph lebih besar dari pada endomorph. Kategori endomorphic mesomorph adalah mesomorph lebih dominan dan endomorph lebih besar dari ectomorph. Sedangkan kategori mesomorphic endomorph adalah endomorph lebih dominan, dan mesomorph lebih besar dari ectomorph (Heath \& Carter, 2002).

Setelah melakukan pengukuran antropometri, kemudian dilakuakan tes kesegaran jasmani yaitu ACSPFT (Asian Committee on the Standarization of Physical Fitness Test) meliputi komponen daya ledak otot, kekuatan, kecepatan, kelenturan, dan ketangkasan (Suryanto \& Sutapa, 2006). Daya ledak otot adalah kemampuan seseorang untuk melakukan kekuatan maksimum, dengan usahanya yang dikerahkan dalam waktu sependek-pendeknya. Daya ledak otot diukur dengan tes lompat jauh tanpa awalan (Widyastuti \& Agus, 2007). Kekuatan adalah kemampuan seseorang pada saat mempergunakan otot-ototnya, menerima beban dalam waktu kerja tertentu. Kekuatan diukur dengan tes angkat badan atau pull up selama 60 detik (Widyastuti \& Agus, 2007). Kecepatan adalah kemampuan seseorang dalam melakukan gerakan keseimbangan dalam bentuk yang sama dalam waktu yang sesingkatsingkatnya. Kecepatan diukur dengan tes lari sprint 50 meter (Widyastuti \& Agus, 2007). Kelenturan adalah kemampuan sendi otot untuk melakukan gerakan dalam ruang gerak sendi. Kelenturan diukur dengan tes lentuk togok ke muka atau forward flexion of trunk (Widyastuti \& Agus, 2007). Ketangkasan adalah kemampuan untuk mengubah gerak tubuh atau posisi tubuh dengan cepat dan tepat tanpa kehilangan keseimbangan. Ketangkasan dikur dengan tes lari hilir mudik atau shuttle run 4x10 meter (Widyastuti \& Agus, 2007). Waktu diukur menggunakan stopwatch dengan ketelitian 0,01 detik dan panjang lapangan diukur menggunakan meteran roll 100 m. Komponen kesegaran jasmani yaitu kecepatan dikategorikan menjadi baik ( $<7$ detik), sedang (7-7,7 detik), dan kurang ( $>7,7$ detik). Daya ledak otot dikategorikan menjadi baik (>214 cm), sedang (203-214), kurang $(<203 \mathrm{~cm})$. Kekuatan dikategorikan menjadi baik (>13 kali), sedang (9-13 kali), dan 
Jurnal Keolahragaan 7 (1), 2019 - 14

Elok Dwi Anggitasari, Fillah Fithra Dieny, Aryu Candra

kurang ( $<9$ kali). Kelenturan dikategorikan menjadi baik $(>16,5 \mathrm{~cm})$, sedang $(14,5-16,5 \mathrm{~cm})$, dan kurang $(<14,5 \mathrm{~cm})$. Ketangkasan dikategori-kan menjadi baik ( $<4,2$ detik), sedang (4,2-5,1 detik), dan kurang ( $>5,1$ detik) (Suryanto \& Sutapa, 2006). Analisa perhitungan kesegaran jasmani merupakan hasil penjumlahan berbagai tes yang telah dilakukan didasarkan pada norma penilaian tes kesegaran jasmanidan dikategorikan menjadi kesegaran jasmani baik (nilai $>375$ ), sedang (nilai 311-375), dan kurang (nilai <311) (Suryanto $\&$ Sutapa, 2006).

Variabel perancu asupan (energi, karbohidrat, protein, dan lemak) merupakan rata-rata asupan harian yang diperoleh melalui wawancara menggunakan recall 3×24 jam. Pengolahan data asupan energi, karbohidrat, protein, dan lemak menggunakan Nutrisurvey 2005. Kebutuhan energi, karbohidrat, protein, dan lemak dihitung berdasarkan kebutuhan masing-masing individu. Tingkat asupan zat gizi dibagi menjadi 3 kategori yaitu asupan lebih $(>100 \%$ dari kebutuhan individu), cukup (80-100\% dari kebutuhan individu), dan kurang $(<80 \%$ dari kebutuhan individu) (Irianto, 2004).

Analisis data statistik menggunakan software statistik. Analisis univariat digunakan untuk menggambarkan karakteristik subyek penelitian, yang meliputi usia, tinggi badan, berat badan, IMT, tebal lemak tubuh (trisep, suprailiaca, subcapular, dan calf), lebar tulang (humerus width dan fumerus width), lingkar tubuh (flixed arm girth, calf girth), asupan energi, karbohidrat, protein, dan lemak. Penentuan status gizi anak remaja dilakukan secara antropometri menggunakan perhitungan Indeks Massa Tubuh menurut Umur (IMT/U) remaja. Karakterisitik IMT/U dikategorikan menjadi kurus $(-3 \leq \mathrm{z}$-skor $<-2)$, normal $(-2 \leq$ z-skor $<+1)$, dan overweight $(+1 \leq$ z-skor $<+2)$ (Kementerian Kesehatan Republik Indonesia, 2011). Analisis bivariat untuk melihat hubungan antara variabel independen (somatotype), variabel perancu (asupan energi, karbohidrat, protein, dan lemak) dengan variabel dependen (kesegaran jasmani), somatotype serta komponen kesegaran jasmani menggunakan uji chi-square bila memenuhi syarat yaitu tidak ada nilai expected kurang dari lima. Bila tidak memenuhi syarat uji chi-square digunakan uji alternatifnya yaitu uji kolmogorov-smirnov. Analisis keeratan hubungan dua variabel dengan menggunakan nilai odds ratio (OR) dilakukan pada variabel somatotype dan variabel perancu dengan kesegaran jasmani.

\section{HASIL DAN PEMBAHASAN}

Tabel 1 menunjukkan bahwa rerata usia subjek 18 tahun dengan berat badan dan tinggi badan maksimum yaitu $85,4 \mathrm{~kg}$ dan $182 \mathrm{~cm}$. Rerata IMT subjek yaitu $21 \mathrm{~kg} / \mathrm{m}^{2}$. Nilai minimum trisep, suprailiaca, subcapular, dan calf skinfold masing-masing yaitu $5 \mathrm{~mm}, 4 \mathrm{~mm}, 6$ $\mathrm{mm}$, dan $3 \mathrm{~mm}$. Rerata humerus width dan fumerus width yaitu $5,5 \mathrm{~cm}$ dan $9,3 \mathrm{~cm}$. Flixed arm girth dan calf girth memiliki nilai minimum yaitu 7,6 cm dan $17 \mathrm{~cm}$. Berdasarkan pengukuran somatotype, rerata somatotype atlet sepak bola adalah 2,8-3,0-3,1 yang tergolong mesomorphicectomorph dengan kecendurungan ectomorph yang lebih dominan dan mesomorph lebih besar dari endomorph. Nilai maksimum asupan energi sebesar $4125 \mathrm{kkal} / \mathrm{hari}$ dan asupan karbohidrat sebesar 625,8 g/hari, sedangkan rerata asupan protein dan lemak subjek masing-masing sebesar $82,6 \mathrm{~g} /$ hari dan $66,5 \mathrm{~g} /$ hari.

Status gizi yang baik diperlukan untuk mempertahankan derajat kebugaran dan kesehatan, membantu pertumbuhan serta menunjang pembinaan prestasi altet. Indeks Massa Tubuh (IMT) seseorang sangat menentukan kemampuan seseorang dalam melakukan kegiatan olahraga. Seseorang memiliki IMT normal akan lebih mampu dalam melakukan kegiatan olahraga. Seseorang yang memiliki status gizi lebih (gemuk) maka akan menurunkan percepatan gerak (Kartika, 2006).

Tabel 2 menunjukkan pada tipe endomorph sebanyak 6 subjek (14,3\%) dalam kategori normal dan 2 subjek (25\%) dalam kategori gemuk. Sebanyak 9 subjek $(81,8 \%)$ dengan tipe mesomorph dalam kategori normal dan 2 subjek $(18,2 \%)$ dalam kategori gemuk. Sedangkan pada tipe ectomorph sebanyak 8 subjek $(34,8 \%)$ dalam kategori kurus dan 15 subjek $(65,2 \%)$ dalam kategori normal.

Status gizi yang gemuk akan membawa pada kebutuhan energi yang lebih besar pada sistem aerobik untuk melalukan dan melangsungkan pergerakan badan. Oleh karena itu, kelebihan berat badan umumnya akan menyebabkan kelelahan yang jauh lebih dini. Penelitian ini menunjukkan tipe ectomorph memiliki status gizi kurus sebanyak 8 atlet. Tingkat asupan yang kurang menjadi penyebab status gizi atlet dalam kategori kurus dimana sumber zat tenaga tidak mencukupi kebutuhan hariannya. Atlet yang memiliki status gizi kurus, akan mengalami penurunan kekuatan, kelenturan dan ketangkasan 
serta penurunan daya tahan kardiovaskular (Penggalih et al., 2016).

Tabel 3 menunjukkan tipe mesomorph memiliki rerata kecepatan 7,3 detik, sedangkan tipe endomorph memiliki rerata kecepatan 7,7 detik. Pada tipe mesomorph memiliki rerata daya ledak otot 228,1 cm, sedangkan tipe endomorph memiliki rerata daya ledak otot $213,6 \mathrm{~cm}$. Rerata ketangkasan tipe endomorph 4,4 detik, sedangkan rerata ketangkasan tipe ectomorph 3,8 detik. Rerata kelenturan pada tipe endomorph $16,3 \mathrm{~cm}$, sedangkan rerata pada tipe mesomorph $18,2 \mathrm{~cm}$. Pada tipe ectomorph memiliki rerata kekuatan 6 kali, sedangkan tipe mesomorph memiliki rerata kekuatan 5,2 kali.

Tabel 1. Karakteristik Subjek Penelitian

\begin{tabular}{lrrr}
\hline \multicolumn{1}{c}{ Variabel } & Minimum & Maksimum & Rerata \pm SD \\
\hline Usia (tahun) & 15 & 20 & $18 \pm 1,6$ \\
Berat Badan $(\mathrm{kg})$ & 40,6 & 85,4 & $61,8 \pm 8,5$ \\
Tinggi Badan $(\mathrm{cm})$ & 155 & 182 & $17,8 \pm 6,2$ \\
IMT $\left(\mathrm{kg} / \mathrm{m}^{2}\right)$ & 16 & 27 & $21 \pm 2,5$ \\
Trisep $(\mathrm{mm})$ & 5 & 15 & $8,8 \pm 2,3$ \\
Suprailiaca $(\mathrm{mm})$ & 4 & 18 & $9 \pm 3$ \\
Subscapular $(\mathrm{mm})$ & 6 & 15 & $9,4 \pm 2,1$ \\
Calf Skinfold $(\mathrm{mm})$ & 3 & 11 & $6,3 \pm 1,6$ \\
Humerus Width $(\mathrm{cm})$ & 4,3 & 7,5 & $5,5 \pm 0,8$ \\
Fumerus Width $(\mathrm{cm})$ & 7,6 & 11,1 & $9,3 \pm 0,8$ \\
Flixed Arm Girth $(\mathrm{cm})$ & 17 & 32 & $25,7 \pm 2,8$ \\
Calf Girth $(\mathrm{cm})$ & 31 & 42 & $35,7 \pm 2,2$ \\
Endomorph & 1,4 & 5,2 & $2,8 \pm 0,8$ \\
Mesomorph & $-2,0$ & 6,8 & $3,0 \pm 1,7$ \\
Ectomorph & 0,5 & 6,5 & $3,1 \pm 1,3$ \\
Asupan Energi $(\mathrm{kkal})$ & 1980 & 4125 & $2539 \pm 443,9$ \\
Asupan Karbohidrat $(\mathrm{g})$ & 197,8 & 625,8 & $335,8 \pm 73,3$ \\
Asupan Protein $(\mathrm{g})$ & 49,4 & 170,7 & $82,4 \pm 20,1$ \\
Asupan Lemak $(\mathrm{g})$ & 42 & 123,7 & $66,5 \pm 14,2$ \\
\hline
\end{tabular}

Tabel 2. Gambaran Somatotype berdasarkan Status Gizi

\begin{tabular}{|c|c|c|c|}
\hline \multirow{2}{*}{ Variabel } & \multicolumn{3}{|c|}{ Status Gizi berdasarkan IMT/U } \\
\hline & Kurus n (\%) & Normal n (\%) & Gemuk n (\%) \\
\hline Somatotype & & & \\
\hline Endomorph & $0(0)$ & $6(14,3)$ & $2(4,8)$ \\
\hline Mesomorph & $0(0)$ & $9(21,4)$ & $2(4,8)$ \\
\hline Ectomorph & $8(19)$ & $15(35,7)$ & $0(0)$ \\
\hline
\end{tabular}

Tabel 3. Karakteristik Somatotype dan Komponen Kesegaran Jasmani

\begin{tabular}{|c|c|c|c|c|c|c|}
\hline \multirow{2}{*}{ Variabel } & \multicolumn{2}{|c|}{ Endomorph } & \multicolumn{2}{|c|}{ Mesomorph } & \multicolumn{2}{|c|}{ Ectomorph } \\
\hline & Rerata & SD & Rerata & SD & Rerata & SD \\
\hline Kecepatan (detik) & 7,7 & 1,2 & 7,3 & 1,2 & 7,1 & 0,9 \\
\hline Daya Ledak Otot $(\mathrm{cm})$ & 213,6 & 9,3 & 228,1 & 10,4 & 229,5 & 13,7 \\
\hline Ketangkasan (detik) & 4,4 & 0,4 & 4,0 & 0,5 & 3,8 & 0,4 \\
\hline Kelenturan $(\mathrm{cm})$ & 16,3 & 5,5 & 18,2 & 4,3 & 21,5 & 3,4 \\
\hline Kekuatan (kali) & 4,0 & 2,6 & 5,2 & 3,0 & 6,0 & 2,5 \\
\hline
\end{tabular}

Tabel 4. Hubungan Somatotype dengan Kecepatan

\begin{tabular}{lrrrr}
\hline \multirow{2}{*}{ Variabel } & \multicolumn{3}{c}{ Kecepatan } & \multirow{2}{*}{$p$} \\
\cline { 2 - 4 } & \multicolumn{1}{c}{ Tinggi $\mathrm{n}(\%)$} & Sedang $\mathrm{n}(\%)$ & Rendah $\mathrm{n}(\%)$ & \\
\hline Somatotype & & & $3(37,5)$ & \multirow{2}{*}{$0,034^{\mathrm{a}}$} \\
Endomorph & $2(25)$ & $3(37,5)$ & $2(18,2)$ & \\
Mesomorph & $5(45,5)$ & $4(36,4)$ & $2(8,7)$ & \\
Ectomorph & $12(52,2)$ & $9(39,2)$ & 2
\end{tabular}

${ }^{\mathrm{a} U j i}$ Kolmogorov-Smirnov 
Jurnal Keolahragaan 7 (1), 2019 - 16

Elok Dwi Anggitasari, Fillah Fithra Dieny, Aryu Candra

Tabel 5. Hubungan Somatotype dengan Daya Ledak Otot

\begin{tabular}{lrrrr}
\hline \multirow{2}{*}{ Variabel } & \multicolumn{3}{c}{ Daya Ledak Otot } & \multirow{2}{*}{\multicolumn{1}{c}{ Kurang n (\%) }} \\
\cline { 2 - 4 } & \multicolumn{1}{c}{ Sedang n (\%) } & & \multirow{2}{*}{ (\%) } \\
Somatotype & $3(37,5)$ & $4(50)$ & $1(12,5)$ & $0,0001^{\mathrm{a}}$ \\
Endomorph & $9(81,8)$ & $2(18,2)$ & $0(0)$ & \\
Mesomorph & $19(82.6)$ & $4(17,4)$ & $0(0)$ & \\
Ectomorph & & &
\end{tabular}

${ }^{\mathrm{a}} \mathrm{Uji}$ Kolmogorov-Smirnov

Tabel 6. Hubungan Somatotype dengan Ketangkasan

\begin{tabular}{lrrrr}
\hline \multirow{2}{*}{ Variabel } & \multicolumn{3}{c}{ Ketangkasan } & \multirow{2}{*}{$p$} \\
\cline { 2 - 4 } & \multicolumn{1}{c}{ Sedang n (\%) } & Kurang n (\%) & \multirow{2}{*}{0} \\
\hline Somatotype & $3(37,5)$ & $3(37,5)$ & $2(25)$ & $0,0001^{\text {a }}$ \\
Endomorph & $5(45.5)$ & $5(45,5)$ & $1(9,1)$ & \\
Mesomorph & $16(69.6)$ & $7(30,4)$ & $0(0)$ & \\
Ectomorph & & &
\end{tabular}

aji Kolmogorov-Smirnov

Tabel 7. Hubungan Somatotype dengan Kelenturan

\begin{tabular}{lrrrr}
\hline \multirow{2}{*}{ Variabel } & \multicolumn{3}{c}{ Kelenturan } & \multirow{2}{*}{$p$} \\
\cline { 2 - 4 } & \multicolumn{1}{c}{ Baik n (\%) } & Sedang n (\%) & Kurang n (\%) & \multirow{2}{*}{0,041} \\
Somatotype & & & $1(12,5)$ & \\
Endomorph & $4(50)$ & $3(37.5)$ & $1(9,2)$ & \\
Mesomorph & $6(54,5)$ & $4(36,3)$ & $1(4,3)$ & \\
Ectomorph & $17(73,9)$ & $5(21,7)$ &
\end{tabular}

${ }^{\mathrm{a} U j i}$ Kolmogorov-Smirnov

Tabel 8. Hubungan Somatotype dengan Kekuatan

\begin{tabular}{lrrrr}
\hline \multirow{2}{*}{ Variabel } & \multicolumn{3}{c}{ Kekuatan } & \multirow{2}{*}{$p$} \\
\cline { 2 - 4 } & \multicolumn{1}{c}{ Kuat $\mathrm{n}(\%)$} & \multicolumn{1}{c}{ Sedang $\mathrm{n}(\%)$} & & \\
\hline Somatotype & & & & \\
Endomorph & $0(0)$ & $3(37,5)$ & $5(62,5)$ & $0,003^{\mathrm{a}}$ \\
Mesomorph & $0(0)$ & $9(81,8)$ & $2(18,2)$ & \\
Ectomorph & $1(4,3)$ & $18(78,3)$ & $4(17,4)$ & \\
\hline
\end{tabular}

${ }^{\mathrm{a} U j i}$ Kolmogorov-Smirnov

Tabel 9. Hubungan Somatotype dengan Kesegaran Jasmani

\begin{tabular}{lrrrr}
\hline \multirow{2}{*}{ Variabel } & \multicolumn{3}{c}{ Kesegaran Jasmani } & \multirow{2}{*}{ Kurang n (\%) } \\
\cline { 2 - 4 } & Baik n (\%) & Sedang n (\%) & \\
\hline Somatotype & & & & \\
Endomorph & $4(50)$ & $3(37,5)$ & $1(12,5)$ & $0,045^{\mathrm{a}}$ \\
Mesomorph & $8(72,7)$ & $3(27,3)$ & $0(0)$ & \\
Ectomorph & $19(82,6)$ & $3(13)$ & $1(4)$ & \\
\hline
\end{tabular}

${ }^{\mathrm{a} U j i}$ Kolmogorov-Smirnov

Tabel 4 menunjukkan tipe ectomorph dan mesomorph merupkan tipe yang memiliki kecepatan tinggi yaitu sebanyak 12 subjek $(52,2 \%)$ dan 5 subjek $(45,5 \%)$, namun kecepatan paling rendah didapatkan pada atlet dengan tipe endomorph sebanyak 3 subjek (37,5\%). Hasil uji bivariat menunjukkan bahwa terdapat hubungan yang signifikan antara somatotype dengan kecepatan dengan nilai $p=0,034$.

Kecepatan merupakan kualitas kondisional yang memungkinkan seorang atlet untuk bereaksi secara cepat bila dirangsang dan untuk melaku- kan gerakan secepat mungkin (Yavuz, 2013). Penelitian ini menunjukkan hubungan yang signifikan antara somatotype dengan kecepatan $(p=0,034)$. Hasil ini sesuai dengan penelitian di Turki tahun 2010, dimana somatotype berhubungan dengan komponen kecepatan (Orhan, Sagir, Zorba, \& Kishali, 2010). Hasil penelitian ini menunjukkan atlet sepak bola posisi penyerang didominasi oleh tipe mesomorphic-ectomorph dan tipe endomorphy ectomorph yang umumya berpostur tubuh kecil, massa lemak rendah, dan massa otot yang sedikit sehingga 
pemain dapat melewati lawan dan mengoper bola jarak jauh atau jarak dekat. Cabang olahraga lain yang memiliki aktivitas anaerobik dan membutuhkan kecepatan adalah atlet sprinter. Penelitian yang dilakukan di Amerika tahun 2012 menunjukkan bahwa atlet spinter lebih didominasi tipe balanced endomorph, tipe mesomorph ectomorph, dan tipe mesomorphic endomorph (Aerenhouts et al., 2012).

Tabel 5 menunjukkan tipe ectomorph dan mesomorph merupakan tipe yang memiliki daya ledak baik yaitu sebanyak 19 subjek $(82,6 \%)$ dan 9 subjek (81,8\%), namun daya ledak paling kurang didapatkan pada atlet dengan tipe endomorph sebanyak 1 subjek (12,5\%). Hasil uji bivariatmenunjukkan bahwa terdapat hubungan yang signifikan antara somatotype dengan daya ledak otot dengan nilai $p=0,0001$.

Daya ledak otot dan kekuatan otot tungkai adalah komponen kondisi fisik yang menyangkut masalah kemampuan seorang atlet pada saat mempergunakan otot-ototnya dan menerima beban dalam waktu kerja tertentu (Akca \& Muniroglu, 2008; Lewandowska, Buśko, Pastuszak, \& Boguszewska, 2011). Penelitian ini menunjukkan hubungan yang signifikan antara somatotype dengan daya ledak otot dan kekuatan otot $(p<0,05)$. Hasil ini sesuai dengan penelitian di Turki tahun 2001 yang menyatakan somatotype berpengaruh tingkat daya ledak seseorang (Akca \& Muniroglu, 2008). Hasil penelitian ini menunjukkan atlet sepak bola didominasi oleh tipe mesomorphic endomorph pada posisi kiper yang cenderung memiliki rangka tubuh besar (termasuk tungkai yang panjang) sehingga dapat mempengaruhi kemampuan melompat, kecepatan reaksi dalam menangkap bola, dan menendang bola. Hasil tersebut berbeda dengan atlet sepak bola pada penelitian di Korea tahun 2015 menyatakan karakteristik atlet sepak bola untuk kiper adalah tipe endomorphic mesomorph (3,55-2) denganpostur tubuh yang tinggi (Noh et al., 2015).

Tabel 6 menunjukkan tipe ectomorph dan mesomorph merupakan tipe yang memiliki ketangkasan baik yaitu sebanyak 16 subjek $(69,6 \%)$ dan $5(45,5 \%)$, namun ketangkasan paling kurang didapatkan pada atlet dengan tipe endomorph sebanyak 2 subjek (25\%). Hasil uji bivariat menunjukkan bahwa terdapat hubungan signifikan antara somatotype dengan ketangkasan dengan nilai $p=0,0001$.

Ketangkasan merupakan kemampuan untuk mengubah gerak tubuh atau posisi tubuh dengan cepat dan tepat tanpa kehilangan keseim- bangan. Penelitian ini menunjukkan hubungan yang signifikan antara somatotype dengan ketangkasan $(p=0,0001)$. Penelitian ini sesuai dengan penelitian di Serbia tahun 2011, dimana somatotype berhubungan dengan komponen ketangkasan (Jeffreys, 2006). Hasil penelitian ini menunjukkan atlet sepak bola didominasi oleh tipe mesomorphic-ectomorph. Hasil tersebut berbeda dengan atlet sepak bola pada umumya dan cabang olahraga lain yang memiliki aktivitas aerob dan anaerob seperti futsal. Penelitian di Brazil tahun 2012 menunjukkan pemian futsal putra lebih didominasi oleh tipe endomorph yang ditandai dengan bentuk tubuh pendek, berat badan rendah, tungkai bawah pendek, pinggul sempit, lingkar pinggul kecil dan lemak tubuh lebih banyak dibandingkan dengan pemain sepak bola yang cenderung memiliki tipe mesomorph (Burdukiewicz, Pietraszewska, Stachon, Chromik, \& Golinski, 2014). Pada penelitian ini, tipe mesomorphic-ectomorph dan tipe endomorphy ectomorph cenderung dimiliki pemain penyerang yang umumnya tidak terlalu tinggi, postur tubuhnya kecil, tangkas dan memiliki ketahanan fisik yang baik ketika di lapangan.

Tabel 7 menunjukkan tipe ectomorph dan mesomorph merupakan tipe yang memiliki kelenturan baik yaitu sebanyak 17 subjek $(73,9 \%)$ dan 6 subjek (54,5\%), namun kelenturan kurang didapatkan pada masing-masing atlet sebanyak 1 subjek. Hasil uji bivariate menunjukkan bahwa terdapat hubungan yang signifikan antara somatotype dengan kelenturan dengan nilai $p=0,041$.

Kelenturan atau fleksibilitas merupakan kemampuan sendi otot untuk melakukan gerakan dalam ruang gerak sendi. Komponen-komponen biomotor akan sangat dipengaruhi oleh tingkat fleksibilitas. Penelitian ini menunjukkan hubungan yang signifikan antara somatotype dengan kelenturan $(p=0,041)$. Hasil ini sesuai dengan penelitian di Polandia tahun 2011 yang menyatakan somatotype berhubungan dengan Fleksibilitas (Church, Wiggins, Moode, \& Et, 2011). Penelitian ini menunjukkan atlet sepak bola didominasi oleh tipe endomorphic mesomorph pada posisi pemain belakang dan tengah yang cenderung memiliki berat yang ideal dengan massa otot yang padat, tungkai yang panjang sehingga memudahkan untuk bergerak dengan leluasa dan lincah dalam memindahkan bola. Cabang olahraga lain yang memiliki aktivitas anaerobik dan membutuhkan komponen kelenturan adalah atlet gulat. Penelitian di Korea tahun 2013 menyatakan atlet gulat cenderung memiliki tipe endomorph yang ditandai bentuk tubuh bulat dengan 
persen lemak tubuh tinggi, lingkar pinggang yang lebar, dan cenderung pendek. Kelenturan yang optimal dapat memperkecil peluang terjadinya cidera persendian dan mengakibatkan peningkatan performa atlet (Noh et al., 2014).

Tabel 8 menunjukkan tipe ectomorph dan mesomorph merupakan tipe yang memiliki kekuatan kategori sedang paling banyak yaitu 18 subjek $(78,3 \%)$ dan 9 subjek $(81,8 \%)$, namun kekuatan paling rendah didapatkan pada atlet dengan tipe endomorph sebanyak 5 subjek $(62,5 \%)$. Hasil uji bivariat menunjukkan bahwa terdapat hubungan yang signifikan antara somatotype dengan kekuatan dengan nilai $p=0,003$.

Tabel 9 menunjukkan tipe ectomorph dan mesomorph merupakan tipe yang memiliki tingkat sesegaran jasmani baik yaitu sebanyak 19 subjek $(82,6 \%)$ dan 8 subjek $(72,7 \%)$, namun kesegaran jasmani kurang dimiliki oleh tipe endomorph dan ectomorph yaitu masing-masing 1 subjek. Hasil uji bivariat menunjukkan bahwa terdapat hubungan yang signifikan antara somatotype dengan kesegaran jasmani dengan nilai $p=0,045$.

Pengukuran somatotype diperlukan dalam proses penyeleksian atlet karena setiap cabang olahraga memerlukan kesesuaian dengan pertimbangan tipe tubuh. Penelitian ini menunjukkan terdapat hubungan signifikan antara somatotype dengan kesegaran jasmani $(p<0,05)$. Berdasarkan pengukuran somatotype, rerata somatotype atlet sepak bola pada penelitian ini adalah 2,8-3-3,1 yang tergolong mesomorphic ectomorph dengan kecendurungan ectomorph yang lebih dominan dan mesomorph lebih besar dari endomorph. Hasil tersebut berbeda dengan atlet sepak bola pada penelitian di Korea tahun 2015 menyatakan karakteristik atlet sepak bola untuk pemain belakang dan pemain tengah umumnya bertubuh tinggi dan memiliki kekuatan otot yang lebih. Somatotype untuk pemain belakang dan pemain tengah ialah endomorphic mesomorph $(3-5-2,5)$. Pemain penyerang pada umumnya tidak terlalu tinggi, postur tubuhnya kecil, tangkas dan memiliki ketahanan fisik yang baik ketika di lapangan. Somatotype untuk pemain penyerang ialah balanced mesomorph (3-4, 5-3). Penelitian tersebut menyatakan bahwa kiper memiliki postur tubuh yang lebih tinggi dengan somatotype endomorphic mesomorph (3,5-5-2) (Noh et al., 2015).

Pernyataan ini juga sesuai dengan hasil penelitian para ahli yang menyatakan bahwa sebagian besar pemain sepak bola didunia mempunyai rerata somatotype berkisar antara endo- morphic mesomorph, balance mesomorph dan ectomorphic mesomorph. Perbedaan somatotype antar beda posisi pemain, disebabkan oleh frekuensi dan jenis latihan yang dilakukan oleh setiap pemain. Hal ini sesuai dengan pernyataan Heath dan Carter, bahwa perubahan-perubahan dalam suatu olahraga termasuk di dalamnya latihan dan teknik-teknik akan dapat mengubah somatotype menjadi lebih baik (Heath \& Carter, 2002).

Tabel 10 menunjukkan subjek yang memiliki asupan energi cukup dengan tingkat kesegaran jasmani baik sebanyak 16 subjek $(69,6 \%)$, sedangkan asupan karbohidrat cukup dengan tingkat kesegaran jasmani baik sebanyak 15 subjek $(71,4 \%)$. Terdapat 9 subjek $(69,2 \%)$ yang memiliki asupan protein cukup dengan tingkat kesegaran jasmani baik, sedangkan yang memiliki asupan lemak cukup dengan tingkat kesegaran jasmani baik sebanyak 11 subjek $(68,8 \%)$. Hasil uji bivariat menunjukkan hubungan yang signifikan antara asupan energi dengan kesegaran jasmani $(p=0,035)$. Namun, tidak terdapat hubungan yang signifikan antara asupan karbohidrat, protein, dan lemak dengan kesegaran jasmani $(p<0,05)$.

Atlet yang usianya masih dalam masa pertumbuhan, zat gizi tidak hanya untuk menunjang aktivitas fisik saja, tetapi juga harus cukup untuk menunjang pertumbuhannya. Secara umum, para atlet memerlukan energi tinggi yang diperoleh dari karbohidrat, lemak, dan protein. Asupan zat gizi yang cukup akan menunjang pertumbuhan fisik yang maksimal, sehingga tubuh akan mencapai bentuk yang paling optimal (Driskell \& Wolinsky, 2011).

Hasil analisis bivariat asupan energi dan karbohidrat menunjukkan terdapat hubungan signifikan antara asupan energi dan karbohidrat dengan kesegaran jasmani $(p<0,05)$. Hasil ini sesuai dengan penelitian yang dilakukan di Inggris tahun 2015, responden yang diberikan makanan berenergi tinggi memiliki performa daya tahan baik (Briggs et al., 2015). Pemberian asupan karbohidrat bagi seorang atlet bertujuan untuk mengisi kembali simpanan glikogen otot dan hati. Atlet yang mempunyai simpanan glikogen sedikit akan cepat mengalami kelelahan (Burke, Hawley, \& Jeukendrup, 2011).

Hasil analisis bivariat menunjukkan tidak terdapat hubungan signifikan antara asupan protein dan lemak dengan kesegaran jasmani $(p>0,05)$. Hasil ini sesuai dengan penelitian di Amerika tahun 2013, atlet sepak bola yang mengonsumsi makanan-makanan berprotein tidak 
berperan langsung dalam produksi energi bagi para olahragawan yang sedang berolahraga (Boisseau, Le Creff, Loyens, \& Poortmans, 2002). Meningkatnya penggunaan lemak selama olahraga memungkinkan terjadinya penghematan cadangan karbohidrat (glikogen) di dalam otot dan menyebabkan meningkatnya daya tahan otot (Hulton, Edward, Gregson, Maclaren, \& Doran, 2013).

Penelitian ini menunjukkan rata-rata atlet sepak bola merupakan atlet remaja yang memiliki kebutuhan gizi khusus untuk pertumbuhan. Kebutuhan tersebut semakin meningkat dengan terdapatnya tambahan aktivitas, seperti pada atlet. Asupan zat gizi yang tidak sesuai dengan kebutuhan dapat menyebabkan gangguan pertumbuhan dan bahkan dapat mengganggu performa atlet (Poblano-alcalá \& Braun-zawosnik, 2014).

Hasil asupan zat gizi menunjukkan rerata pemenuhan asupan energi, karbohidrat, lemak, dan protein dalam kategori kurang. Hal tersebut apabila dibiarkan terjadi secara berkelanjutan maka akan dapat mengganggu pemenuhan energi selama latihan dan pertandingan. Berdasarkan pemeriksaan antropometri menunjukkan sebesar $34,8 \%$ subjek dengan tipe ectomorph dalam kategori kurus. Konsumsi asupan yang kurang dengan aktivitas yang tinggi pada atlet maka berisiko mengalami status gizi kurang.
Tabel 11 merupakan hasil analisis multivariat yang menunjukkan asupan energi dan somatotype merupakan variabel yang paling berhubungan terhadap kesegaran jasmani. Subjek yang memiliki tipe mesomorphic-endomorph beresiko 1,5 kali lebih besar memiliki kesegaran jasmani kurang (95\% CI: 0,043 - 5,671), sedangkan subjek yang memiliki asupan energi kurang beresiko 2,2 kali lebih besar memiliki kesegaran jasmani kurang dibandingkan subjek yang tidak mengonsumsi energi cukup (95\% CI: 0,260 $18,141)$. Sedangkan probabilias subjek memiliki kesegaran jasmani kurang dipengaruhi oleh asupan energi dan somatotype sebesar 53,5\%.

Hasil ini sesuai dengan penelitian yang dilakukan di Inggris tahun 2015 yang menyatakan bahwa responden yang diberi makanan berenergi tinggi memiliki performa daya tahan baik (Briggs et al., 2015). Makanan yang dimakan dapat mempengaruhi tingkat glikogen otot dan performa daya tahan. Keseimbangan energi mengacu pada pemasukan energi yang diperoleh dari makanan dan pengeluaran energi yang digunakan dalam aktivitas sehari-hari. Konsumsi makanan yang berenergi tinggi pada atlet baik untuk kebugaran, performa, dan kesehatan. Atlet yang mencukupi cadangan energi berupa energi yang terdapat dalam otot dan hati akan meningkatkan stamina sehingga tidak mudah mengalami kelelahan dan dapat mempertahankan daya tahan seorang atlet (Driskell \& Wolinsky, 2011).

Tabel 10. Hubungan Asupan Energi, Karbohidrat, Protein, Lemak dengan Kesegaran Jasmani

\begin{tabular}{lrrrr}
\hline \multirow{2}{*}{ Variabel } & \multicolumn{3}{c}{ Kesegaran Jasmani } & \multirow{2}{*}{$p$} \\
\cline { 2 - 4 } & Baik n (\%) & Sedang n (\%) & Kurang n (\%) \\
\hline Asupan energi & $16(69,6)$ & $6(26,1)$ & $1(4,3)$ & $0,035^{\mathrm{a}}$ \\
$\quad$ Cukup & $14(78,9)$ & $3(15,8)$ & $1(5,3)$ & \\
$\quad$ Kurang & $15(71,4)$ & $5(23,8)$ & $1(4,8)$ & $0,041^{\mathrm{a}}$ \\
Asupan karbohidrat & $16(76,2)$ & $4(19)$ & $1(4,8)$ & \\
$\quad$ Cukup & & $3(23,1)$ & $1(3,4)$ & $0,310^{\mathrm{a}}$ \\
$\quad$ Kurang & $22(75,2)$ & $6(20,7)$ & $1(3,4)$ & \\
Asupan protein & $11(68,8)$ & $4(25)$ & $1(6,2)$ & $0,420^{\mathrm{a}}$ \\
$\quad$ Cukup & $20(76,9)$ & $5(19,2)$ & $1(3,8)$ & \\
$\quad$ Kurang & & & & \\
Asupan lemak & & &
\end{tabular}

${ }^{a}$ Uji Kolmogorov-Smirnov

Tabel 11. Analisis Multivariat Variabel yang Mempengaruhi Kesegaran Jasmani

\begin{tabular}{lcccc}
\hline \multicolumn{1}{c}{ Variabel } & Koefisien (B) & $p$ & OR & $95 \%$ CI \\
\hline Somatotype & 0,709 & $0,042^{\mathrm{a}}$ & 1,5 & $0,043-5,671$ \\
Asupan Energi & 0,776 & $0,031^{\mathrm{a}}$ & 2,2 & $0,260-18,141$ \\
Asupan Karbohidrat & 0,445 & $0,100^{\mathrm{a}}$ & 1,6 & $0,088-4,671$ \\
Konstanta & $-1,630$ & & & \\
\hline
\end{tabular}

${ }^{\mathrm{a} U j i}$ Regresi Logistik Ganda 
Menurut hasil pengukuran somatotype pada penelitian ini diketahui bahwa sebagian besar somatotype pada atlet sepak bola belum sesuai dengan para pemain sepak bola pada umumnya. Rerata somatotype atlet sepak bola penelitian ini adalah 2,8-3,0-3,1 yang tergolong mesomorphic ectomorph dengan kecendurungan ectomorph yang lebih dominan dan mesomorph lebih besar dari endomorph. Hasil tersebut kurang sesuai dengan rerata hasil pengukuran somatotype atlet sepak bola Turki tahun 2010 yaitu balancedmesomorph (2,9-4,6-2,6), selain itu somatotype pada atlet sepak bola remaja Spanyol tahun 2010 yaitu balanced mesomorph (2,4-4,3-2,4) (Gil, Ruiz, \& Irazusta, 2010; Hazir, 2010). Sedangkan penelitian di Indonesia tahun 2015 menunjukkan rerata somatotype atlet sepak bola di Wisma Atlet Ragunan Jakarta adalah 2,66,6-2,9 tergolong balanced mesomorph (Penggalih et al., 2016). Namun, berdasarkan hasil penelitian pada pemain sepak bola Unit Kegiatan Mahasiswa Universitas Gajah Mada tahun pelatihan 2014/2015 sebanyak 9 pemain atau sebesar $36 \%$ mengarah pada tipe tubuh ideal pemain sepak bola dengan kategori endomorphic mesomorph, balancemesomorph dan ectomorphic mesomorph. Sedangkan sebanyak 16 pemain atau sebesar $64 \%$ tidak mengarah pada tipe tubuh ideal pemain sepak bola dengan kategori central, mesomorph endomorph, balance ectomorph dan endomorphic ectomorph (Pratiwi, 2015).

Meskipun hasil pengkajian somatotype yang masih belum sesuai dengan referensi, namun bentuk tubuh atlet masih dapat berubah ke arah yang lebih baik seiring dengan masa pertumbuhan pada atlet dan pembentukan massa otot. Oleh karena itu, perlu adanya intervensi pada faktor-faktor yang dapat mendukung atlet sepak bola untuk mencapai somatotype yang diharapkan seperti halnya dilakukan intervensi pada asupan gizi dan latihan yang teratur. Hasil ini sesuai dengan penelitian di Florida tahun 2002 menyatakan usia 13-18 tahun adalah fase pertumbuhan oleh karena itu bentuk latihan dan durasi latihan dari intensitas ringan sampai dengan berat perlu diperhatikan untuk pembentukan daya tahan fisik atlet usia remaja. Hasil penelitian tersebut juga ditunjang dengan adanya kebutuhan asupan energi yang cukup sehingga dapat mendukung terbentuknya tipe tubuh yang optimal (Battinelli, 2007).

\section{SIMPULAN}

Berdasarkan hasil analisis tipe ectomorph dan mesomorph memiliki kecepatan, daya ledak otot, ketangkasan, kelenturan, kekuatan, dan kesegaran jasmani lebih baik dibandingkan tipe endomorph. Asupan energi dan somatotype merupakan variabel yang paling berhubungan dengan kesegaran jasmani.

\section{DAFTAR PUSTAKA}

Aerenhouts, D., Delecluse, C., Hagman, F., Taeymans, J., Debaere, S., van Gheluwe, B., \& Clarys, P. (2012). Comparison of anthropometric characteristics and sprint start performance between elite adolescent and adult sprint athletes. European Journal of Sport Science, 12(1), 9-15. https://doi.org/10.1080/17461391.2010.53 6580

Akca, F., \& Muniroglu, S. (2008). Anthropometric-somatotype and strength profiles and on-water performance in Turkish elite kayakers. International Journal of Applied Sports Sciences, 20(1), 22-34.

Battinelli, T. (2007). Physique, fitness, and performance. Boca Raton: CRC Press LLC.

Berning, J. (2004). Nutrition for exercise and sports performance. Philadelphia: WB Saunders Company.

Boisseau, N., Le Creff, C., Loyens, M., \& Poortmans, J. R. (2002). Protein intake and nitrogen balance in male non-active adolescents and soccer players. European Journal of Applied Physiology, 88(3), 288-293. https://doi.org/10.1007/s00421002-0726-x

Briggs, M., Cockburn, E., Rumbold, P., Rae, G., Stevenson, E., \& Russell, M. (2015). Assessment of energy intake and energy expenditure of male adolescent academylevel soccer players during a competitive week. Nutrients, 7(10), 8392-8401. https://doi.org/10.3390/nu7105400

Burdukiewicz, A., Pietraszewska, J., Stachon, A., Chromik, K., \& Golinski, D. (2014). The anthropometric characteristics of futsal players compared with professional soccer players. Human Movement, 15(2), 93-99. https://doi.org/10.2478/humo-2014-0008

Burke, L., Hawley, J., \& Jeukendrup, A. (2011). Carbohydrates for training and competition. Jounal of Sports Sciences, 
29(1), 17-27.

Church, J., Wiggins, M., Moode, F., \& Et, A. (2011). Effect of warm-up and flexibility treatments on vertical jump performance. Journal of Strength Condition Research, 15, 332-336.

Departemen Kesehatan Republik Indonesia. (2005). Pedoman pelatihan gizi olahraga untuk prestasi. Dirjen Kesehatan Masyarakat Direktorat Gizi Masyarakat.

Driskell, J., \& Wolinsky, I. (2011). Nutritional assessment of athletes. Boca Raton: Taylor $\&$ Francis Group.

Evendi, D. (2015). Somatotype pemain sepak bola unit kegiatan mahasiswa UNY tahun pelatihan 2014/2015. Universitas Negeri Yogyakarta, Yogyakarta.

Fink, H., Burgon, L., \& Mikesky, A. (2006). Practical applications in sport nutrition. Boston: Jones and Bartlett Publishers.

Gil, S. M., Ruiz, F., \& Irazusta, A. (2010). Anthropometrical characteristics and somatotype of young soccer players and their comparison with the general population. Biology of Sport, 27(1), 17-24. https://doi.org/10.5604/20831862.906762

Hazir, T. (2010). Physical characteristics and somatotype of soccer players according to playing level and position. Journal of Human Kinetics, 26(October), 83-95. https://doi.org/10.2478/v10078-010-0052$\mathrm{Z}$

Heath, B. H., \& Carter, J. L. (2002). A modified somatotype method. American Journal of Physical Anthropology, 27(1), 251-267.

Hulton, A., Edward, J., Gregson, W., Maclaren, D., \& Doran, D. (2013). Effect of fat and $\mathrm{CHO}$ on intermittent exercise in soccer players. International Journal Sport Medical, 34, 165-169.

Irianto, D. P. (2004). Bugar dan sehat dengan berolahraga. Yogyakarta: Andi Offset.

Irianto, D. P. (2007). Panduan latihan kebugaran yang efektif dan aman. Yogyakarta: CV Lukman Offset.

Jeffreys, I. (2006). Motor learning-applications for agility, part 1. Strength and Conditioning Journal, 28(5), 72-76. https://doi.org/10.1519/00126548200610000-00012

Kartika, E. (2006). Hubungan tingkat konsumsi gizi (energi, protein, besi) dan status gizi (indeks massa tubuh, kadar hemoglobin) dengan ketahanan fisik pada atlet sepak bola di PSIS Semarang. Universitas Negeri Semarang, Semarang.

Kementerian Kesehatan Republik Indonesia. (2011). Standar antropometri penilaian status gizi anak. Jakarta: Direktorat Bina Gizi.

Lewandowska, J., Buśko, K., Pastuszak, A., \& Boguszewska, K. (2011). Somatotype variables related to muscle torque and power in judoists. Journal of Human Kinetics, 30(1), 21-28. https://doi.org/10.2478/v10078-011-0069$\mathrm{y}$

Noh, J.-W., Kim, J.-H., Kim, M.-Y., Lee, J.-U., Lee, L.-K., Park, B.-S., ... Kim, J. (2014). Somatotype analysis of elite boxing athletes compared with nonathletes for sports physiotherapy. Journal of Physical Therapy Science, 26(8), 1231-1235. https://doi.org/10.1589/jpts.26.1231

Noh, J.-W., Kim, M.-Y., Lee, L.-K., Park, B.-S., Yang, S.-M., Jeon, H.-J., ... Kim, J. (2015). Somatotype and body composition analysis of Korean youth soccer players according to playing position for sports physiotherapy research. Journal of Physical Therapy Science, 27(4), 10131017. https://doi.org/10.1589/jpts.27.1013

Orhan, Ö., Sagir, M., Zorba, E., \& Kishali, N. F. (2010). A comparison of somatotypical values from the players of two football teams playing in Turkcell Turkish super league on the basis of the players ' positions. Journal of Physical Education and Sport Management Vol., 1(July), 110.

Penggalih, M. H. S. T., Pratiwi, D., Fitria, F., Sari, M. D. P., Narruti, N. H., Winata, I. N., ... Kusumawati, M. D. (2016). Identifikasi somatotype, status gizi, dan dietary atlet remaja stop and go sports. Jurnal Kesehatan Masyarakat, 11(2), 222. https://doi.org/10.15294/kemas.v11i2.449 5

Poblano-alcalá, A., \& Braun-zawosnik, D. (2014). Differences among somatotype, body composition and energy availability in Mexican pre-competitive female gymnasts. Food and Nutrition Sciences, 5(March), 533-540.

Pratiwi, D. (2015). Hubungan somatotype dan 
Jurnal Keolahragaan 7 (1), 2019 - 22

Elok Dwi Anggitasari, Fillah Fithra Dieny, Aryu Candra

performa fisik pada atlet sepak bola tim nasional (timnas) U-19 dan atlet sepak bola mahasiswa. Universitas Gadjah Mada, Yogyakarta.

Suryanto, \& Sutapa, P. (2006). Penilaian tes kesegaran jasmani dengan ACSPFT dan TKJI. Jurnal Medikora, 2(11), 147-160.

Tóth, T., Michalíková, M., Bednarčíková, L., Živčák, J., \& Kneppo, P. (2014). Somatotypes in sport. Acta Mechanica et Automatica, 8(1), 27-32. Retrieved from https://content.sciendo.com/view/journals/ ama/8/1/article-

p27.xml?rskey $=7 \mathrm{AW} 16 \mathrm{~b} \&$ result $=1$
Ulvie, \& Setiwati, Y. (2011). Tingkat Kesegaran Jasmani, Status Gizi dan Asupan Zat Gizi Makan Pagi pada Atlet Sepak Bola Kota Semarang. Jurnal Media Ilmu Keolahragaan Indonesia, 1(1), 20-21.

Whitney, E., \& Rolfes, S. (2007). Understanding nutrition. McGraw Hill.

Widyastuti, E., \& Agus, S. (2007). Pendidikan jasmani olahraga dan kesehatan. Jakarta: Yudhistira.

Yavuz, S. C. (2013). Somatotype and physical fitness profiles of 6-12 year-old girls. The International Journal of Social Scienses, $8(1), 76-86$. 